\title{
The Effectiveness of the English Conversation to Improve Students' Speaking Skill
}

\author{
Suparman \\ STIT Palapa Nusantara Lombok NTB \\ lalusuparman2@gmail.com
}

\begin{abstract}
The study was aimed to examine the effectiveness of the English conversation to improve students' speaking skill focusing on whether English conversation effective in speaking skill and how is the effectiveness of the English conversation to improve students' speaking skill. The research was designed in a pre-experimental pre-test and posttest research, where the research only applied the English conversation to the experimental group that consisted of 28 students. The sample of the study was taken by using cluster random sampling technique. It was taken randomly of 148 second grader students of MTs. Negeri Masbagik as the population of the study. The gaining data of pre-test and post-test was taken by requiring the students to make and practice a conversation in front of the class based on the material that was learnt before. Later, the pre-test and post-test data was analyzed by using descriptive statistics and Paired Sample t-test to test the hypothesis. Having collected and calculated the data by using descriptive statistics, the present researcher found out that descriptive statistic result showed the mean score of the pre-test was 7.21 while the mean of the post-test was 9.25. The result of hypothesis testing by using Paired-Sample t-test was $\mathrm{t}_{(27)}=11.68$ at $p=$ .000 . It was lower than .05 so it means that the null hypothesis (Ho) was rejected and the alternative hypothesis $(\mathrm{Ha})$ was accepted. In other word that the English conversation was significantly effective in speaking skill.
\end{abstract}

Key word: English conversation, speaking skill

\section{Introduction}

Language is one of the most important things in communication and it is used as a tool of communication among the nations in all over the world Language is the communication by voice in the distinctively human manner, using arbitrary sounds in conventional ways with conventional meanings ${ }^{1}$. Language is a set of symbols being used mainly for communication. The symbols may be spoken or written. Language is an aspect of human behavior. In written form it is a long-term

${ }^{1}$ Dictionary Com “What is Language”. Available : http://www.dictionary.combrowse/language 
record of knowledge from one generation to the next while in spoken form it is a means of communication. Language is the key aspect of human intelligence ${ }^{2}$. Language, a system of conventional spoken, manual, or written symbols by means of which human beings, as members of a social group and participants in its culture, express themselves. The function of language include communication, the expression of identity, play, imaginative expression, and emotional release. In most accounts, the primary purpose of language is to facilitate communication, in the sense of transmission of information from one person to another ${ }^{3}$. Consequently, the existence of the language take an important place in our daily life.

The English language has become an international language. Among nations it serves as a lingua franca. It is spoken, learnt and understood even in those countries where it is not a native's language. English is playing a major role in many sectors including education, medicine, engineering, advanced studies, business, technology, banking, computing, tourism etc. As a result, English is being taught and learned around the world as a second language today ${ }^{4}$.

Since language is a tool of communication, we communicate with others, to express our ideas, and to know other's ideas as well. Communication takes place, where there is speech. Without speech we can not communicate with one another ${ }^{5}$.

In Indonesia, English is considered as the first foreign language and taught formally from elementary school up to the university level in the form of four skills, listening, speaking, reading, and writing. The four language skills of listening, speaking, reading, and writing are all interconnected. Proficiency in each skill is necessary to become a well-rounded communicator, but the ability to speak skillfully provides the speaker with several distinct advantages. The capacity to put words together in meaningful way to reflect thoughts, opinions, and feelings provides the

\footnotetext{
2Robin[2013]'Whatislanguage".Available:http://language.worldofcomputing.net/linguistics/introduct ion/what-is-language.html

3 David Crystal, Robert Henry Robins [2013]" Language ". Available: https://www.britannica.com/topic/language

${ }^{4}$ Ishrat Aamer Qureshi,The Importance of Speaking Skills for EFL Learners ( online ) Dep.of English, Alama Iqbal Univ. Available : ishrataamer@hotmail.com

${ }^{5}$ Ibid
} 
speaker with these important advantages, such $a s^{6} ;(1)$ ability to inform, persuade, and direct, (2) ability to stand out from the rest,

( 3 ) ability to benefit derivatively, and ( 4 ) career enhancement. We use language in a variety of situations. The teachers at their work place, i.e. The English Teacher teaching in a real English class are supposed to lead the students speak correctly and effectively in-order to communicate well as it is targeted to the gaining competency. At junior high school, English lesson is lead the students to gain a certain literacy level. The level of literacy is functional, where the students asked to communicate oral or written in case of daily live. The importance of speaking skill, hence is enormous for the students of English Subject at school. For a smooth running of any techniques, the students of English language need to be especially and purposefully in the skill of speaking.

In the context of English language learning, however there is a problem which students have been aware of for a long time. It is the problem of the students who are structurally competent but who cannot communicate appropriately in speaking. In order to overcome this problem the process involved in fluent conversation need to be dealt with to develop speaking skill. It is the technique of English conversation.

Conversation is the kind of speech that happens informally, symmetrically, and for the purposes of establishing and maintaining social ties, follow rules of etiquette because conversation are social interactions. It is generally face-to-face person-to-person at the same time (synchronous $)^{7}$. Conversation enables participants to ; $(1$ ) learn something from a great deal of conversation, ( 2 ) coordinating our action in ways that are mutually and, ( 3 ) coordination of action assumes relatively clear goals ${ }^{8}$. Not only can conversational skills be learned and developed, but it is surprisingly easy to do so, especially if we follow some of the rules. They $\operatorname{are}^{9}$ ( 1 ) Conversation is a Two-Way Street, (2) be friendly and polite, ( 3 ) respond to what they are saying, (4) use the signaling to help the other person,

\footnotetext{
6 Gerald Gillis [2013]”The importance of speaking skills “. Available : http://www.geraldgillis.com/importance-speaking-skills/

7 Wikipedia " Definition and characterization ". Available : https://en.wikipedia.org/wiki/Conversation.

8 Hugh Dubberly and Paul Pangaro" How can we design an effective conversation". Available:http.//www.dubberly.com/articles/what-is-conversation.html

9 "Conversational skills". Available : https://www.skillsyouneed.com/ips/conversational-skills.html
} 
and ( 5 ) create emotional connections. Both motor- receptive skills and interaction adeptness are usually required in conversation. Many times this pairing calls upon effective understanding of the two in order to implement oral exercises in an effective manner. Motor skills involve perceiving, recalling, and articulating in the correct order sounds and structures of the language. Interaction skills involve making decisions about communication, such as what to say and how to say it. Keeping in mind the difference, the class level should play a large part in determining which of the two skills are predominately used during the course.

While speaking was found by students as a problem, teachers must creative to find out an appropriate method to make students interest, more pleasant, and more enjoyable in speaking class. To make the effectiveness of English conversation in teaching speaking the teacher should lead the students to facilitate their oral production. The students can ease the oral production of speech in the following manner ${ }^{10}$ a) Simplifying structure which can be found in the tendency to tack new sentences on to previous ones by the use of coordinating conjunctions : like, and, or but. b ) The ellipsis technique : By using the ellipsis technique when conversing the speaker is able to omit parts of speech in order to speak economically. c) formulaic expression : speech pattern consisting of conventional colloquial or idiomatic expressions. Idiomatic expression consist of all kinds of set phrases and although such sayings usually flow together in a set conversation pattern. d) fillers and hesitation devices : such as, " you see", " kind of " you know " can used in order to give the speakers more time to formulate and organize their ideas while speaking.

In order to help students' activity in speaking, a teacher should look for an effective technique to make learning English easier, more pleasant, and more enjoyable. To make speaking easier, the technique like conversation is supposed as one of the effective technique to improve speaking skill, and was interested to be investigated whether it is effective in speaking skill and how is its effectiveness to improve students' speaking skill.

10 Mark Coughlin [2006 ] “Teaching Speaking and Conversation “ Open Journal 


\section{Methods}

\section{A. Research Design}

To know the effectiveness of the English conversation to improve students' speaking skill the designed of the study was pre-experimental method with one class which established the regular instruction to one group by the treatment of English conversation. The group have been given the pre-test before treatment, and after the treatment the group would be given post-test to find out the effectiveness of the treatment.

\section{B. Population and Sample}

1. Population of the Study

The population of this research was at the eighth grader of MTs.Negeri Masbagik in the academic year 2017-2018. The number of population 148 students consisted of five classes.

2. Sample of the Study

The number of the sample and the respondent was 28 students' where chosen VIII/ a by using cluster random sampling technique.

\section{Data Collection}

1. Variable Identification

a. Independent variable was conversation

b. Dependent variable was speaking

2. Variable Definition

a. Conversation

Conversation $^{11}$ is an informal talk involving two people or a small group of people, the act of talking in an informal way, something that is similar to spoken conversation. In other sides conversation ${ }^{12}$ is a talk between two or more people in which thoughts, feelings, and ideas are expressed.

b. Speaking

Speaking is ${ }^{13}$ a productive skill that can be directly and empirically observed, those observations are invariably colored by the accuracy and

11 Merriam-Webster “ Definition of conversation “( Online ) Available https://www.merriamwebster.com.com.

${ }^{12}$ Cambridge English Dictionary. Available https://dictionary.cambridge.org>conver

${ }^{13}$ Brown H.D.[2001]'Principle of language teaching and learning. Engelwood Cliffs NJ: Prentice Hall America. 
fluency. While, he also states that speaking is the product of creative construction of linguistic strings, the speakers make choice of lexical, structure, and discourse.

\section{Instrument}

The assessment of the speaker is measured according to ${ }^{14}$ fluency, lexical accuracy, grammatical accuracy, and word pronunciation accuracy.

\section{Assessment of the speakers}

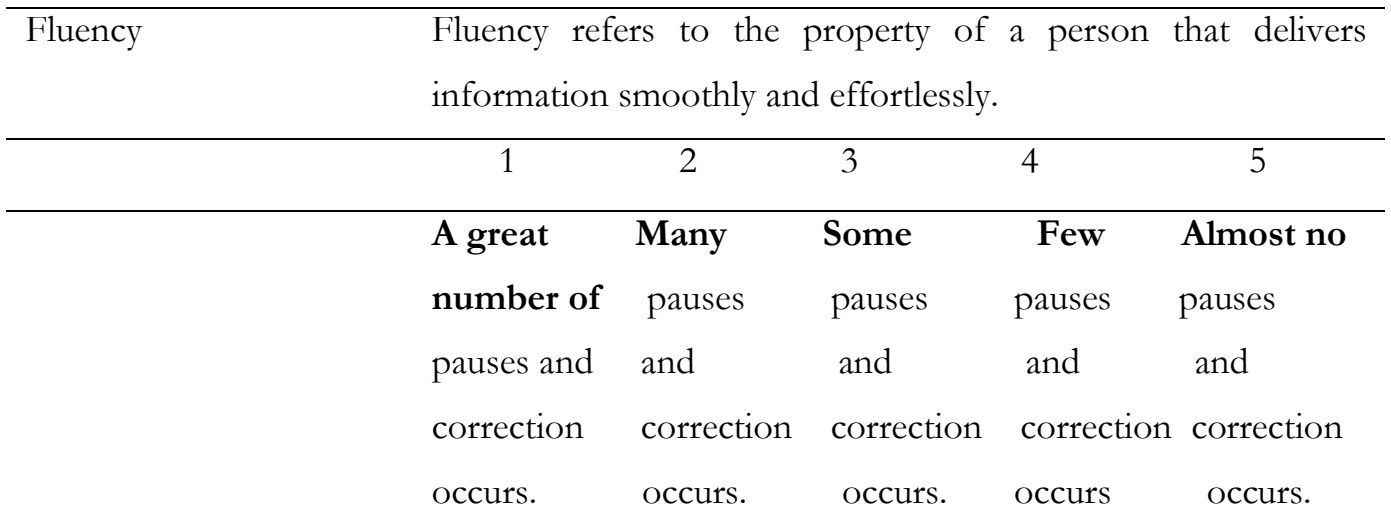

\begin{tabular}{lllllc}
\hline Lexical Accuracy & $\begin{array}{l}\text { Lexical accuracy refers to the ability to use vocabulary } \\
\text { properly. }\end{array}$ \\
\hline 1 & 2 & 3 & 4 & 5 \\
\hline A great & Many & Some & Few & Almost no \\
& number of & lexical & lexical & lexical & lexical \\
& lexical & errors are & errors are errors are & errors are \\
& errors are & present. & present. & present. & present. \\
& present. & & & &
\end{tabular}

Grammatical Accuracy The ability use grammatical structure properly.

$\begin{array}{lllll}1 & 2 & 3 & 4 & 5\end{array}$

${ }^{14}$ Moejito [2014]"Basic Statistics for Research in Language Education. STKIP Hamzanwadi Selong 


\begin{tabular}{lllccc}
\hline A great & Many & Some & Few & Almost no \\
number of & grammatical & grammatical & grammatical & grammatical \\
grammatical & errors are & errors are & errors are & errors are \\
errors are & present. & present. & present. & present. \\
present. & & & &
\end{tabular}

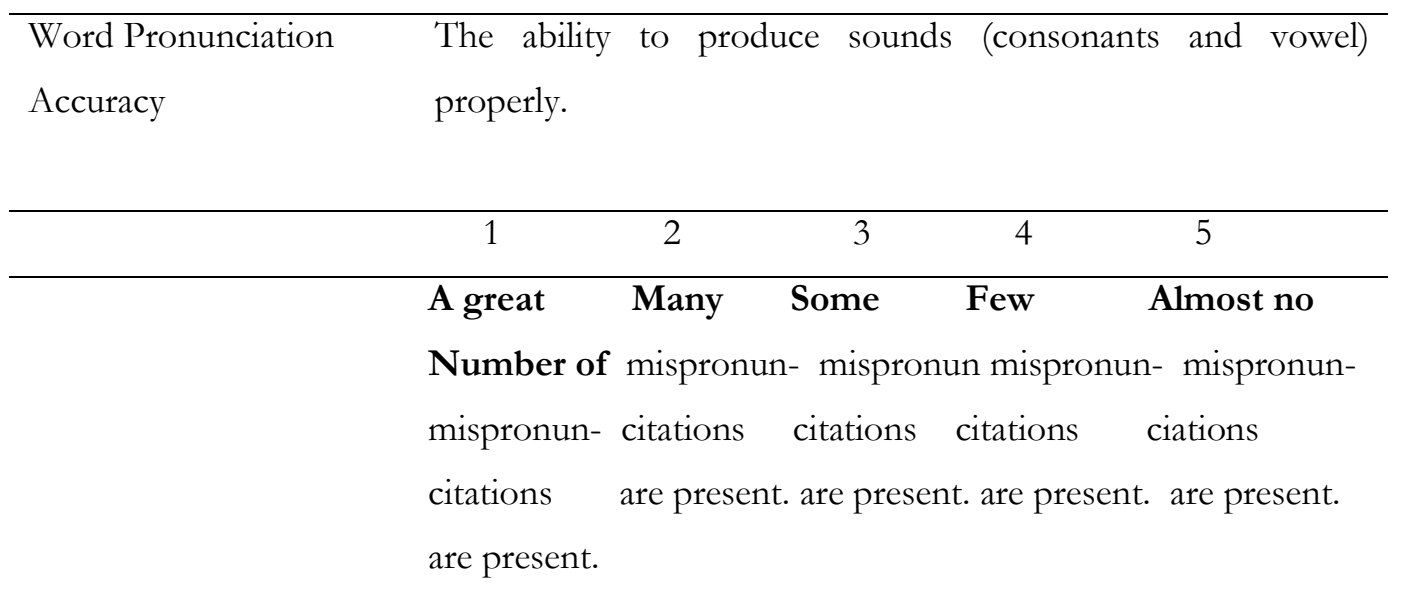

\section{Technique of Collecting Data}

a. Pre-test

This test applied before teaching the students by using English conversation.

b. Treatment

The treatment was given to the students by using English Conversation.

c. Post-test

The test was given after applying treatment.

\section{Data Analysis}

Descriptive statistics was used to analyze the qualitative data that was gained in the pre-test and post-test. All of the process was computed by using SPSS Statistics 17 for Windows.

1. Descriptive Statistics

The data was analyzed by using the descriptive statics to analyze the gaining data. It was started by calculating the mean score of the pre-test and post-test by using SPSS Statistic 17 for Windows. The mean showed a single 
score that indicated students' speaking skill. Then, the next step was finding out standard deviation. It was needed to calculate the degree to which the group of scored deviated from the mean. It was started by putting the analyzed data, then went to menu bar and selected Analyze, then selected Descriptive Statistics, and the standard deviation of the mean was automatically shown in SPSS Statistic Viewer.

2. Testing Hypothesis

a. Normality Testing

It was used to know whether or not the data had normal distribution. Before testing the hypothesis, the normality test for the data had to be conducted first. To find out the normal distribution, it was opened the entering data then went to analyze. The next step was selecting nonparametric test then 1-sample K-S. In One-Sample KolmogorovSmirnov $\mathrm{Z}$ dialog box, selected the variables from the left to variable on the right. It was continued by putting a tick in the box of normal of test distribution then OK. As the result, the output of One-Sample Kolmogorov-Smirnov Z was displayed in SPSS Statistic Viewer. If the values of the significance level of investigation variables are greater than 0.05 , the distribution of the data is normal ${ }^{15}$.

b. Homogeneity

After calculating the normal distribution, the data then checked its homogeneity of the variance of the variables. It was begun by going to Analyze, then compares Means, and then One-Way ANOVA. In OneWay ANOVA dialog box, it was selected the variables the clicked on option. It was continued by putting a tick in homogeneity of variance test in option box. As the last step, the present researcher clicked ready then $\mathrm{OK}$. The result of homogeneity of variance test displayed. If the values of the significance level of the investigation variables are greater than 0.05, the variance of each variable was homogeneous ${ }^{16}$

c. Testing Hypothesis

15 Moejito [2014]"Basic Statistics for Research in Language Education. STKIP Hamzanwadi Selong 16 Moejito [2014 ]"Basic Statistics for Research in Language Education. STKIP Hamzanwadi Selong 
To analyze the hypothesis testing which aimed at knowing whether the alternative hypothesis was accepted or not, it was used SPSS 17 to know the effectiveness of the English conversation in teaching speaking from experimental group. To the next step the data which would be calculated then continued by going to menu bar and choosing Analyze menu, then selecting Compare Means, and then clicked Paired Samples ttest. In Paired Sample t-test dialog box, the present researcher selected the variables to be tested. As the output, the SPSS statistic showed the result of the procedure which indicated that the hypothesis was accepted or rejected.

\section{RESULT AND DISCUSSION}

\section{A. Result}

The finding of the study was description about the effectiveness of the English conversation to improve students' speaking skill. The data of pre-test and post-test was gained from the experimental group by using English conversation which consisted of 28 students and the score interval that were used to determine students' speaking skill was $4-15$. So, the minimum score was 4 and the maximum score was 15.

Based on the data gained, the highest score on pre-test was 10 and the lowest score was 4 with the mean score 7.21, standard deviation was 3.16 and variance was 9.95, while on post-test, the highest score was 15 and the lowest score was 6 with the mean score was 9.25, standard deviation was 2.77 and variance was 7.67.

The gained data showed that there was an increase in speaking skill of the students after the treatment was given by using English conversation. It was indicated by mean score of the post-test that was higher than the pre-test

Students' score on pre-test and post-test

\begin{tabular}{ccc}
\hline & Pre-Test & Post-Test \\
\hline$N$ & 28 & 28 \\
\hline$x$ & 7.21 & 9.25 \\
\hline
\end{tabular}




\begin{tabular}{ccc}
\hline$S$ & 3.16 & 2.77 \\
\hline$s^{2}$ & 9.95 & 7.67 \\
\hline & & Where:
\end{tabular}

$$
\begin{array}{ll}
N & =\text { number of students } \\
x & =\text { mean score } \\
s & =\text { standard deviation } \\
s^{2} & =\text { variance }
\end{array}
$$

Based on the given data above, it could be seen that there was a difference between students' speaking score after and before the treatment was implemented. Mean score of the students' after teaching by using English conversation was higher than mean score of the students' before treatment was implemented.

Normal distribution test is needed in order to find out whether the data is in normal distribution or not. The normal distribution data indicated that the sample of the study was taken from the population that had normal distribution. If the value of the significance level of the investigated variable is higher than 05 , it means that implied distribution of data was normal. ${ }^{17}$

The Calculation of Normal Distribution Test

\begin{tabular}{ccc} 
& Pre-Test & Post-Test \\
\hline$N$ & 28 & 28 \\
\hline Colmogorov-Smirnov Z & .991 & .976 \\
\hline Asym. Sig (2-tailed) & .280 & .296 \\
\hline
\end{tabular}

Based on the output data of normal distribution test by using One-Sample Kolmogorov-Smirnov $\mathrm{Z}$ test as shown above, the value of the Asymp. Sig. (2tailed) on the pre-test and post-test was higher than 05. It indicated that the data was in normal distribution ${ }^{18}$.

After knowing that the sample was in normal distribution, the next was counting the homogeneity test. The homogeneity test was calculated by using One-Way ANOVA test. It was used to find out whether the data was

${ }^{17}$ Moedjito [2014 ] Basic Statistics for Research in Language Education.

18 Moedjito [2014 ] Basic Statistics for Research in Language Education. 
homogenous or not. If the significance level the data was higher than .05 , it meant the data was homogenous. But if the was lower than .05 , it meant the data was not homogenous.

Test of Homogeneity of V ariance

\begin{tabular}{lcccc}
\hline \multicolumn{5}{c}{ Pre-post test } \\
& $\begin{array}{l}\text { Levene } \\
\text { Statistic }\end{array}$ & $d f 1$ & $d f 2$ & Sig. \\
\hline Score based & .424 & 5 & 19 & .826 \\
on mean & & & & \\
\hline
\end{tabular}

Based on the data that was shown above it can be seen that the significance level of data was .826. It was higher than 05. It means that the data was homogenous.

Based on normal distribution and homogeneity test that had been done, it showed that the data was normal and homogenous, so it was continued by doing the hypothesis test by using Paired Sample t-test, which was determined the confidence interval of the difference was $95 \%$ and the standard significance (2tailed) value level was 05 .

If the significance (2-tailed) value level of the analyzed data was lower than 05 , it means the alternative hypothesis $(\mathrm{Ha})$ is accepted and the null hypothesis (Ho) is rejected. But if it is higher than 05 the alternative hypothesis $(\mathrm{Ha})$ is rejected and the null hypothesis (Ho) is accepted.

Hypothesis Test by Using Paired-Sample T-Test

\begin{tabular}{cccccc} 
& \multicolumn{3}{c}{ 95\% Confidence Interval } & & Sig. $(2-$ \\
& & & & Of the Difference \\
& & $t$ & tailed $)$ \\
\hline Pair 1 & Pretest & & -11.680 & 27 & .000 \\
& Posttest & & & & \\
\hline
\end{tabular}


The above data shown that the significance (2-tailed) tailed value level of the analyzed data was 000 . It is lower than 05 , so it means that the alternative hypothesis $(\mathrm{Ha})$ was accepted and the null hypothesis $(\mathrm{Ho})$ was rejected.

\section{B. Discussion}

It can be elaborated that using English conversation was effective in teaching speaking to the eighth grader in the academic year 2017-2018. The first statement of the problem proposed in the previous "Is English conversation effective in speaking skill at the eighth grader of MTs.Negeri Masbagik in the academic year 2017-2018?" The result analysis on the effectiveness of the English conversation in speaking skill was presented in the table descriptive statistic on experimental group. The students became more active in the class, the students became more confidence to communicate with the other friends by using English, and there was a warming class condition.

By taking the design of this research was one group pre-test and posttest design, therefore it was concerned about gaining the qualitative data through pre-test and post-test in order to figure out the effectiveness level of the given treatment to the subject of the study.

In this research, the meeting was conducted for 10 times, 6 times meeting for treatment by using English conversation and 2 times meeting for pre-test, and than 2 times meeting for post-test. The mean score of the pre-test was 7.21 and the standard deviation was 3.16. While the mean score of the posttest was 9.25 and the standard deviation was 2.77. It meant, the result of the post-test was higher than the pre-test. While the result of t-test by using paired sample t-test showed that the English conversation was significantly effective in speaking skill to the eight grader of MTs.Negeri Masbagik in the academic year 2017-2018.

The purpose of learning language is to be able to communicate whether in oral or written form. This natural way of communication can be applied in speaking class by doing question and answer. The term of question and answer 
was not focused on the difficulty level of material in communication but, it was focused on comprehending the material of communication ${ }^{19}$.

\section{CONCLUSION AND IMPLICATION}

\section{A. Conclusion}

The result of this study was that the mean score of post-test was higher than the pre-test and the result of t-test by using paired sample t-test showed that significance value level was lower than .05. It means that the English conversation was significantly effective in speaking skill for the eighth grader of MTs.Negeri Masbagik in the academic year 2017-2018.

\section{B. Implication}

Based on the result of this study, it is suggested that:

1. In applying the English conversation in teaching and learning process, teachers should pay more attention to the students' skill in making conversation with their friends.

2. The implementation of the English conversation in teaching and learning process makes students become more active in classroom.

3. We have more warming class by implementing Conversation.

4. English teachers have to give more opportunity to the students in order to practice their speaking skill to increase their fluency in using the target language.

5. English teachers should motivate their students to speak English either inside or outside the classroom.

\section{Bibliography}

${ }^{19}$ Krashen, S. D. (1997). Foreign language education the easy way. Culver City E, CA: Language Education Associates 
Brown, H.D. (2001). Principle of language teaching and learning. Engelwood Cliffs NJ: Prentice Hallp America.

Cambridge English Dictionary. Retrieved from https://dictionary.cambridge.org>conv. Visited on October 2017

Conversation Skills.Retrieved from:https://www.skillsyouneed.com/lips/conversationalskills.htmal. Visited on October 2017.

David Crystal,Robert Henry Robins ( 2013 ) “ Language” Retrieved from “ https:/www.britannica.com/topic/language. Visited on October 2017.

Dictionary Com. What is Language. Retrieved from: https://www.dictionary.combrwse/language. Visited on October 2017

Gerald Gills ( 2013 ) . The Importance of Speaking Skills . Retrieved from:http://www.geraldgillis.com/importance-speaking-skills. Visited on October 2017.

Hugh Dubberly and Paul Pangaro . How Can We Design an Effective Conversation . Retrieved from: $\quad$ http://www.dubberly.com/Articles/what-isconversation.html. Visited on October 2017.

Ishrat Aamer Qureshi. The Importance of Speaking Skills for EFL Learners

( online ). Dept. of English, Alama Iqbal Univ. Retrieved from: ishrataamer@hotmail.com. Visited on October 2017.

Krashen, S.D ( 1997 ) Foreign Language Education The Easy Way. Culver City E. CA : Language Education Associates.

Mark Coughlin (2016). Teaching Speaking and Conversation ( On line journal)

Merriam-Webster. Definition of Conversation. Retrieved from : https://www.merriamwebster.com>conversation. Visited on October 2017.

Moejito ( 2014 ) Basic Statistics for Research in Language Education. STKIP Hamzanwadi Selong. 
Robin ( 2013 ). What is Language. Retrieved from: http://language.worldcomputing.net/linguistics/introduction/what-islanguage.html. Visited on October 2017.

Wikipedia. Defition and Characterization. Retrieved from https://en.wikipedia.org/wiki/conversation. Visited on October 2017. 